\title{
Mining bee Andrena (Agandrena) agilissima (Hymenoptera: Andrenidae): A new record from India with morphological and molecular notes
}

\author{
Gurpreet Singh Makkar ${ }^{1}$, Debjani Dey ${ }^{2}$ and Pardeep K. Chhuneja ${ }^{3 *}$ \\ ${ }^{1}$ Department of Plant Breeding and Genetics, Punjab Agricultural University, Ludhiana-141004 (Punjab), INDIA \\ ${ }^{2}$ Division of Entomology, Indian Agricultural Research Institute, Pusa-110001, New Delhi, INDIA \\ ${ }^{3 *}$ Department of Entomology, Punjab Agricultural University, Ludhiana-141004 (Punjab), INDIA \\ *Corresponding author. E-mail: pkchhuneja@pau.edu
}

Received: January 22, 2016; Revised received: July 31, 2016 Accepted: October 6, 2016

\begin{abstract}
The mining bee Andrena agilissima (Scopoli, 1770), is recorded for the first time in India from the western agro-climatic zone of its Punjab state. This is the first account of morphological and molecular characteristics of $A$. agilissima. This new record now increases the number of mining bees known in India to 21 . Taxonomic comments and metric values of 40 morphological characters have been presented. The mean values for body length, head width, compound eye length, median ocellus diameter, forewing length and hamuli number were $14.04 \pm 0.04 \mathrm{~mm}$, $4.26 \pm 0.003 \mathrm{~mm}, 2.327 \pm 0.008 \mathrm{~mm}, 0.255 \pm 0.005 \mathrm{~mm}, 12.75 \pm 0.022 \mathrm{~mm}$ and $17.00 \pm 0.00$, respectively. Using the standard barcoding protocols, cytochrome $c$ oxidase subunit 1 marker (standard DNA barcode region) based $658 \mathrm{bp}$ DNA barcode sequence of the species has been established, as a first step towards the DNA barcode library of solitary bees of Punjab. The barcode sequence generated for the species has been registered by GenBank, National Centre for Biotechnology Information (NCBI) under accession 'KT960836' and Barcode of Life Data (BOLD) Systems under Barcode Index Number 'BOLD:AAY6909'. The floral sources for A. agilissima in Punjab are also provided. The results can be used to further study the races/ecotypes in different parts of country, habitat management studies, plant-pollinator interactions and in conservation programmes for the species. Further, the precise identification of $A$. agilissima and the inventory of its foraging plants would provide new opportunities for its potential use as pollinator of crops.
\end{abstract}

Keywords: Andrenidae, Andrena agilissima, DNA barcoding, Morpho-taxonomy, New species record

\section{INTRODUCTION}

The genus Andrena Fabricius (Andreninae: Andrenini) comprises of 1,526 described species worldwide (Ascher and Pickering, 2016) and is found throughout holarctic region, in south of Western Hemisphere upto Panama, where one species occurs in tropical lowlands; in Africa through the Eastern African highlands and south to the Cape of Good Hope, and in Asia to the mountains of southern India and of Malaysia (Michener, 2007). It was the fourth genus of bees to be proposed after Apis Linnaeus, 1758; Eucera Scopoli, 1770 and Nomada Scopoli, 1770. Currently 2,955 species in 49 genera of andrenidae are known in the world, but from India, only a single genus, Andrena has been reported so far (Ascher and Pickering, 2016). Most Andrena bees are solitary and a few are communal as $A$. agilissima. The Andrena bees are commonly known as sand or mining bees owing to their behaviour of building nests in soil preferably light sandy soils. There are 104 subgenera recognized under genus Andrena (Ascher and Pickering, 2016). The diversity of Andrena bees is relatively low in India with only 20 species (Ascher and Pickering, 2016) when compared to USA (1206), Mexico (526), Turkey (348) and Spain (219) and other parts of the world. The 20 species of Andrena in India included Andrena aegyptiaca Friese, 1899; Andrena anonyma Cameron, 1897; Andrena arima Cameron, 1909; Andrena bellidoides LaBerge, 1968; Andrena burkelli Bingham, 1908; Andrena cineraria (Linnaeus, 1758); Andrena communis Smith, 1879; Andrena cussariensis Morawitz, 1886; Andrena flavipes Panzer, 1799; Andrena floridula Smith, 1878; Andrena fuscosa Erichson, 1835; Andrena gracillima Cameron, 1897; Andrena leaena Cameron, 1907; Andrena mephistophelica Cameron, 1897; Andrena morose Cameron, 1897; Andrena patella Nurse, 1903; Andrena pilipes Fabricius, 1781 ; Andrena rothneyi Cameron, 1897; Andrena rupshuensis Cockerell, 1911 and Andrena savignyi Spinola, 1838.

The present information on diversity, biology, colony organization, nesting characteristics and foraging plants of Andrena bees in India and the Punjab in particular, is inadequate. The present investigations were thus aimed at establishing precise morphological and molecular identification of $A$. agilissima as a first step towards an inventory of Andrena bees of Punjab and for their potential use as pollen vector of food crops in a planned manner. 


\section{MATERIALS AND METHODS}

Specimen collection: Specimens examined in the study were collected during the day time, while sweeping the flowers of Brassica napus L. and Brassica juncea (L.) Czern.in western agro-climatic zone $\left(30^{\circ}\right.$ $25^{\prime} 6.9^{\prime \prime} \mathrm{N}$ and $\left.74^{\circ} 36^{\prime} 1.8^{\prime \prime} \mathrm{E}\right)$ of Punjab, India at 275 a.s.1. during spring of 2014.

Morphometry: The measurements were made with image acquisition programmed zoom-stereo microscope (Olympus Cell^A Imaging Solutions for Life Science Microscopy). Five worker bees were used for recording the morpho-taxonomic data. Terminology and measurements here follow those of Michener (2007) and Ruttner (1988). The indices and their abbreviations used are as per given.

1) body length (BL), 2) head/ face length (HdL), 3) head width (HdW), 4) thorax length (ThL), 5) thorax width (ThW), 6) abdomen length (AbL), 7) abdomen width $(\mathrm{AbW}), 8)$ clypeus length $(\mathrm{CL}), 9)$ clypeus width $(\mathrm{CW}), 10)$ lower inter-orbital distance (LIOrD), 11) upper inter-orbital distance (UIOrD), 12) interorbital distance through antennal sockets (IOrDas), 13) clypeoantennal distance (CAD), 14) compound eye length (CEL), 15) compound eye width (CEW), 16) distance between antennal sockets (DbAS), 17) interocellar distance (IOD), 18) ocellocular distance (OOcuD), 19) antennocellar distance (AOD), 20) antennocular distance (AOcuD), 21) clypeocular distance (COcuD), 22) median ocellus diameter (MOD), 23) labrum length (LL), 24) labrum width (LW), 25) antennal socket maximum diameter (ASD), 26) scape length (SL), 27) scape diameter (SD), 28) pedicel length (PdL), 29) flagellum length $(\mathrm{FgL}), 30) 3^{\text {rd }}$ flagellomere diameter (3FgmD), 31) forewing length (FwL), 32) forewing width (FwW), 33) hindwing length (HwL), 34) hindwing width (HwW), 35) jugovannal index (JVI), 36) hamuli number (HN), 37) hind tibia length (HTL), 38) hind basitarsus length (HbtL), 39) hind basitarsus width (HbtW) and 40) number of flagellomeres (FgmN). The observations pertaining to the bilateral body-parts such as eyes, antennae, legs and wings were taken on right side body part. The data on metric values is presented as Mean $\pm \mathrm{S}$.E.m.

DNA extraction and PCR reaction: The bee specimens were preserved in a DNA-friendly fashion by immersion in 100 percent ethanol and kept at $-20^{\circ} \mathrm{C}$ in vertical deep freezer till DNA was isolated. DNA extraction was done using previously standardized CTAB method (Cubero et al 1999). CTAB was two per cent solution of cetyltrimethyl ammonium bromide (CTAB) in $100 \mathrm{mMTris} . \mathrm{Cl}(\mathrm{pH}=8.0)$, which additionally contained $20 \mathrm{mM}$ of $\mathrm{Na}_{2}$ EDTA $(\mathrm{pH}=8.0)$ and $1.4 \mathrm{M} \mathrm{NaCl}$. DNA isolation was carried using hind legs tissue of the bee. The primer pair, Forward - 5'ATTCAACCAATCATAAAGATATTGG3' and Reverse 5'TAAACTTCTGGATGTCC AAAAAATCA3' were used to amplify $658 \mathrm{bp}$ fragment of COI gene. All
PCR amplifications were accomplished in a programmable DNA thermolcycler (Mastercycler Gradient Eppendorf ${ }^{\mathrm{TM}}$ ) using the following PCR programme: Step 1: Initial denaturation at $94^{\circ} \mathrm{C}$ for 5 minutes (one cycle); Step 2: Initial denaturation at $94^{\circ} \mathrm{C}$ for $1 \mathrm{~min}$ ute; Step 3: Primer annealing at $55{ }^{\circ} \mathrm{C}$ for 1 minute; Step 4: Primer extension at $72{ }^{\circ} \mathrm{C}$ for 2 minutes; Step 5: Repeated step 2 to 4 (35 cycles); Step 6: Final extension at $72{ }^{\circ} \mathrm{C}$ for 5 minutes and storing the PCR product at $4{ }^{\circ} \mathrm{C}$. Each PCR product was subsequently gel purified. The purified DNA fragments were ligated into a 'PCR product cloning plasmid vector $\mathrm{pTZ57R/T}$ (Fermentas Life Sciences, USA)'. The ligation reaction product was transformed into Escherichia coli DH5alpha host cells using 'InsTAClone ${ }^{\mathrm{TM}}$ PCR cloning kit (M/s Fermentas Life Sciences)' using manufacturer's protocol followed by custom sequencing from Xcelris Labs, Ahmedabad. The natural orientation of sequence was determined by aligning of sequence with the reported sequences (in GenBank database, www.ncbi.nlm.nih.gov/ pubmed/) for the species using 'Gene align function' of the DNA software program 'CLC Free Workbench ver 7.5. of CLC Bio A/S'.

\section{RESULTS AND DISCUSSION}

The new record of $A$. agilissima increases the number of mining bees known in India now to 21 .

\section{Systematics of species:}

Family: Andrenidae Latreille, 1802

Subfamily: Andreninae Latreille, 1802

Genus: Andrena Fabricius

Subgenus: Agandrena Warncke

Andrena (Aganderna) agilissima (Scopoli, 1770)

Material examined: India (5 workers): 3 qq , Muktsar, in western agroclimatic zone of Punjab, from B. napus, 25.ii.2014, 30²2'55" N and 74³8'19.9" E, $275 \mathrm{~m}$ a.s.l., coll.G.S. Makkar; $29 q$, Muktsar, in western agroclimatic zone of Punjab, from $B$. juncea, 11.ii.2014, $30^{\circ} 25^{\prime} 6.9^{\prime \prime} \mathrm{N}$ and $74^{\circ} 36^{\prime} 1.8^{\prime \prime} \mathrm{E}$;, $275 \mathrm{~m}$ a.s.1., coll.G.S. Makkar. Vouchers are deposited in the collection of Punjab Agricultural University Insect Museum and National Pusa collection (NPC), Indian Agricultural Research Institute (IARI), New Delhi. The identity of the species was confirmed by Dr Debjani Dey, Incharge of Insect Identification Service, NPC, IARI, New Delhi, India.

New record: India: Bhullar and Doda in Muktsar at $30^{\circ} 28^{\prime} 30^{\prime \prime} \mathrm{N} 74^{\circ} 30^{\prime} 54^{\prime \prime} \mathrm{E}$, falling in western agroclimatic zone of Punjab.

Diagnosis: Workers of this species are conspicuous amongst other species of Andrena by several distinctive characters (Fig. 1-8) including shiny black body with tufts of velvety hairs on the facial fovea, on either side of thorax, on last abdominal tergite and on the femora of the third pair of legs. The wings have bluish reflections. Dimensions (Table 1): $\mathrm{BL}=14.04 \pm 0.04$ $\mathrm{mm}, \mathrm{HdL}=2.953 \pm 0.001 \mathrm{~mm}, \mathrm{HdW}=4.260 \pm 0.003$, 
Table 1. Measurements (mm) of workers of Andrena agilissima collected in India.

\begin{tabular}{|c|c|c|}
\hline S.No. & Character measurement & *Mean \pm S.E.m \\
\hline 1 & Body length & $14.041 \pm 0.040$ \\
\hline 2 & Head/Face length & $2.953 \pm 0.001$ \\
\hline 3 & Head width & $4.260 \pm 0.003$ \\
\hline 4 & Thorax length & $4.990 \pm 0.004$ \\
\hline 5 & Thorax width & $3.292 \pm 0.004$ \\
\hline 6 & Abdomen length & $7.806 \pm 0.003$ \\
\hline 7 & Abdomen width & $4.286 \pm 0.003$ \\
\hline 8 & $\begin{array}{l}\text { Clypeus length (antero- } \\
\text { posterior) }\end{array}$ & $1.388 \pm 0.005$ \\
\hline 9 & Clypeus width (maximum) & $2.375 \pm 0.005$ \\
\hline 10 & Lower inter-orbital distance & $2.622 \pm 0.003$ \\
\hline 11 & Upper inter-orbital distance & $2.728 \pm 0.004$ \\
\hline 12 & $\begin{array}{l}\text { Inter-orbital distance through } \\
\text { antennal sockets }\end{array}$ & $2.867 \pm 0.022$ \\
\hline 13 & Clypeoantennal distance & $0.056 \pm 0.002$ \\
\hline 14 & Compound eye length & $2.327 \pm 0.008$ \\
\hline 15 & Compound eye width & $0.756 \pm 0.003$ \\
\hline 16 & $\begin{array}{l}\text { Distance between antennal } \\
\text { sockets }\end{array}$ & $0.497 \pm 0.004$ \\
\hline 17 & Interocellar distance & $0.383 \pm 0.002$ \\
\hline 18 & Ocellocular distance & $0.897 \pm 0.005$ \\
\hline 19 & Antennocellar distance & $0.779 \pm 0.002$ \\
\hline 20 & Antennocular distance & $0.880 \pm 0.002$ \\
\hline 21 & Clypeocular distance & $0.123 \pm 0.001$ \\
\hline 22 & Median ocellus diameter & $0.255 \pm 0.005$ \\
\hline 23 & Labrum length & $0.145 \pm 0.002$ \\
\hline 24 & Labrum width & $0.304 \pm 0.002$ \\
\hline 25 & $\begin{array}{l}\text { Antennal sockets maximum } \\
\text { diameter }\end{array}$ & $0.369 \pm 0.002$ \\
\hline 26 & Scape length (Rt.) & $1.061 \pm 0.009$ \\
\hline 27 & Scape diameter (Rt.) & $0.244 \pm 0.003$ \\
\hline 28 & Pedicel length (Rt.) & $0.199 \pm 0.004$ \\
\hline 29 & Flagellum length (Rt.) & $3.735 \pm 0.014$ \\
\hline 30 & 3rd flagellomere diameter & $0.228 \pm 0.005$ \\
\hline 31 & Forewing length (Rt.) & $12.747 \pm 0.022$ \\
\hline 32 & Forewing width (Rt.) & $3.715 \pm 0.006$ \\
\hline 33 & Hindwing length (Rt.) & $9.362 \pm 0.019$ \\
\hline 34 & Hindwing width (Rt.) & $2.693 \pm 0.009$ \\
\hline 35 & Jugovannal Index & $65.609 \pm 0.110$ \\
\hline 36 & Hamuli number & $17.00 \pm 0.000$ \\
\hline 37 & Hind-tibia length (Rt.) & $3.700 \pm 0.007$ \\
\hline 38 & Hind-basitarsus length (Rt.) & $2.269 \pm 0.005$ \\
\hline 39 & Hind-basitarsus width (Rt.) & $0.383 \pm 0.002$ \\
\hline 40 & Number of flagellomeres & $10.000 \pm 0.000$ \\
\hline
\end{tabular}

$\mathrm{CEL}=2.327 \pm 0.008, \mathrm{CEW}=0.756, \mathrm{MOD}=$ $0.255 \pm 0.005, \quad 3 \mathrm{FgmD}=0.228 \pm 0.005, \quad \mathrm{FwL}=$ $12.75 \pm 0.022$ and $\mathrm{FwW}=3.715 \pm 0.006 \mathrm{~mm}$. The other important measurements (means in $\mathrm{mm}$ ) of the species were LIOrd $=2.62, \mathrm{IOrDas}=2.87, \mathrm{IOD}=0.38$ and $\mathrm{OOcuD}=0.89$. The hamuli number in the species was 17. Hind tibia $1.63 \mathrm{x}$ longer than hind basitarsus, hind basitarsus $5.92 \mathrm{x}$ longer than wide, compound eye $3.078 \mathrm{x}$ longer than wider, abdomen $1.005 \mathrm{x}$ longer than head and thorax combined, stigma broader than prestigma (measured to wing margin). Dehon et al. (2014) studied morphological characterisitics of a male andrenid bee, Andrena antoinei Michez \& De Meulemeester sp. nov. and reported head $2.56 \mathrm{~mm}$ long, 2.30

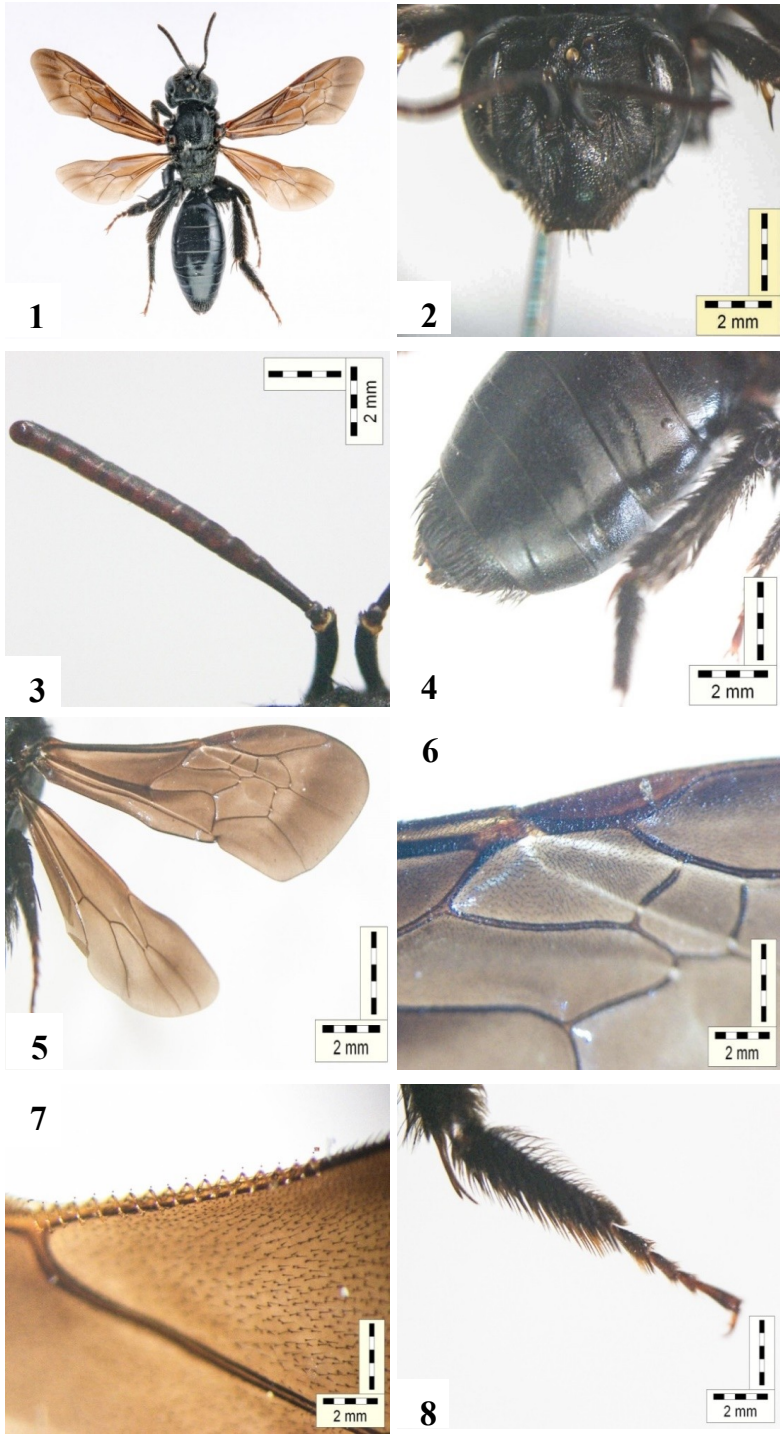

Fig. 1-8. Worker of Andrena agilissima (Scopoli 1770). 1. Mounted view. 2. Frontal view of head. 3. Antennal scape, pedicel and flagellomeres. 4. Tufts of velvety hairs on last abdominal tergites. 5. Fore and hind wing. 6. Stigma and prestigma. 7. Hamuli of hindwing. 8. Velvety hairs on femora of hind legs.

mm wide; compound eyes $1.62 \mathrm{~mm}$ long, $0.53 \mathrm{~mm}$ wide; scape $0.4 \mathrm{~mm}$ long; pedicel $0.27 \mathrm{~mm}$ long; Forewing $5.94 \mathrm{~mm}$ long, $1.53 \mathrm{~mm}$ wide.

Male: Known from other parts of world but not yet recorded from India.

Geographical distribution: The species was previously known from most of Europe, in the Near East and in North Africa with around 332 specimen records vide bee specimen record database of American Museum of Natural History (Anonymous, 2015). The activity period of the species in palearctic region extends from April to July. In West Mediterranean region, the species is present in Slovenia in the Soča valley, near Strunjan (subMediterranean region) and Maribor (sub-Pannonian re- 


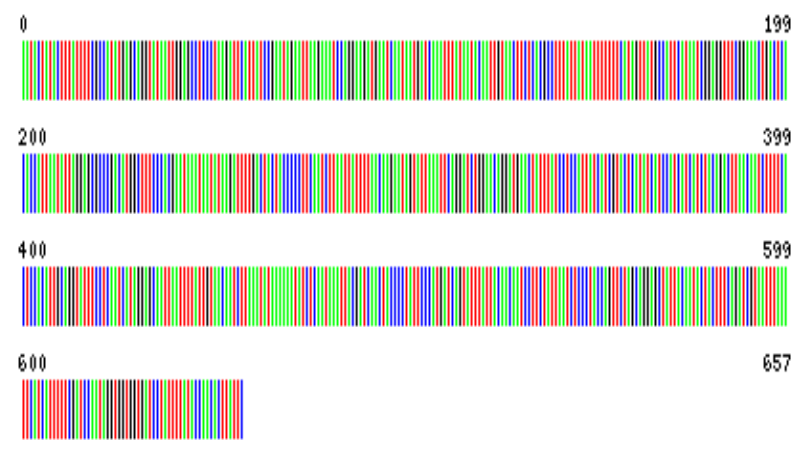

Fig. 9. Illustrative DNA barcode of Andrena agilissima based on COI gene based sequence.

gion), with activity period from May to June.

Nesting biology: Excavate the nests in burrows in the ground. This bee is a communal bee where about 5-50 females share a nest entrance. Several females of the same generation share the same nest, dug in sandy soil, on the river banks or on steep walls. Usually the nests have a common entrance, but each individual has its own brood cells with its egg. It is univoltine species.

Floral associations: It is oligolectic bee and thus collect pollen from only a few flowering plants. We collected this species foraging on $B$. napus and $B$. juncea flowers. Females carry pollen on the hind tibia, hind femora, and on the trochanter, that carriy a group of long hairs forming another basket, the floccus. Nectar is transported to the nest internally in the crop, as in other bees. However, Giovanetti et al. (2006) reported its feeding only on pollen of a few genera of Cruciferous vegetables (Brassicaceae species, as Brassica napus, Brassica rapa, Raphanus raphanistrum, Barbarea vulgaris and Sinapis species).

Molecular characterization: DNA barcoding offer a highly precise means of species identification using mitochondrial gene, cytochrome $c$ oxidase I (COI) (Hebert et al., 2003). We generated 658 bp DNA barcode of A. Agilissima by using protocols discussed earlier. The sequence composition was Adenine (222), Guanine (74), Cytocine (136) and Thymine (226). The edited sequence of $T$. iridipennis was put in a BLAST (Basic Local Alignment Search Tool) search to compare our sequence with GenBank database of sequences to identify the database sequences that resemble our sequence. Based on this alignment, $A$. helvola, A. tibialis, A.nigroaenea and A. nigrospina showed 89.26, 89.21, 88.94 and $88.94 \%$ sequence similarity, respectively to $A$. agilissima. The COI gene based sequence of this species has been made available in GenBank, NCBI (http://www.ncbi.nlm. nih.gov/) under accession 'KT960836' and Barcode of Life Data Systems (BOLD) (http://www.boldsystems.org) under BIN 'BOLD:AAY6909'. The illustrative DNA barcode of the species is presented in Fig. 9.

\section{Conclusion}

A. agilissima is morphologically distinguishable from A. Savignyi Spinola, another common andrenid species of our region, though both have common host range and activity period in Punjab. However, A. agilissima is relatively more aggressive forager of Brassica flora. The present state of knowledge of diversity, biology, colony organization, nesting characteristics and foraging plants of andrenid bees of India and the Punjab in particular, is inadequate, and thus, systematic investigations are desired to completely understand all these attributes for realizing higher honey harvests as well as for their commercial utilization as pollen vectors in Brassica centred agro-ecosystem. DNA barcoding established mitochondrial COI based sequence database for precise species level identification. Additional collections and investigations are needed to completely understand the diversity, distribution and floral associations of andrenids in Punjab and for their potential utilization for effective crop pollination.

\section{ACKNOWLEDGEMENTS}

Authors extend sincere thanks to the Incharge, Insect Identification Service, National Pusa Collection, Indian Agricultural Research Institute, New Delhi for identification of bee specimens.

\section{REFERENCES}

Anonymous (2015). The Global biodiversity Information Facility: GBIF Backbone Taxonomy. http://www.gbif.org/ species/1356870. Accessed 26 November 2015.

Ascher, J.S. and Pickering, J. (2016). Discover Life: Apoidea Species Guide. http://www.discoverlife.org. Accessed 5 January 2016.

Cubero, O.F., Crespo, A., Fatehi, J. and Bridge, P.D. (1999). DNA extraction and PCR amplification method suitable for fresh herbarium-stored, lichenized and other fungi. Plant Syst. Evol., 216: 243-249

Dehon, M., Michez, D., Nel, A., Engel, M. and De Meulemeester, T. (2014). Wing shape of four new bee fossils (Hymenoptera: Anthophila) provides insights to bee evolution. PLoS ONE, 9 (10): e108865

Giovanetti, M., Luppino, S. and Zola, R. (2006). Preliminary note on the relative frequencies of two bees on wild Brassicaceae: oligolectic Andrena agilissima vs polylectic Apis mellifera. Bull. Insectol., 59 (2): 153156

Hebert, P.D.N., Cywinska, A., Ball, S.L. and deWaard, J.R. (2003). Biological identifications through DNA barcodes. Proc. R. Soc. Lond. B Biol. Sci., 270: 313-321

Michener, C.D. (2007). The Bees of the World. Johns Hopkins University Press, Baltimore, Maryland, USA. pp 992.

Ruttner, F. (1988). Biogeography and Taxonomy of Honey Bees. Springer-Verlag, Berlin, Germany. pp 284 